\title{
Beta-3 adrenergic agonists reduce pulmonary vascular resistance and improve right ventricular performance in a porcine model of chronic pulmonary hypertension
}

\author{
Ana García-Álvarez ${ }^{1,2}$ - Daniel Pereda ${ }^{1,2}$ - Inés García-Lunar ${ }^{1,3}$ • David Sanz-Rosa ${ }^{1}$. \\ Rodrigo Fernández-Jiménez ${ }^{1,4} \cdot$ Jaime García-Prieto $^{1} \cdot$ Mario Nuño-Ayala $^{1}$ • \\ Federico Sierra $^{1}$ - Evelyn Santiago ${ }^{2}$ - Elena Sandoval ${ }^{2} \cdot$ Paula Campelos $^{2}$. \\ Jaume Agüero $^{1}$ - Gonzalo Pizarro ${ }^{1,3}$ • Víctor I. Peinado ${ }^{2,5} \cdot$ Leticia Fernández-Friera $^{1,6}$. \\ José M. García-Ruiz ${ }^{1,7} \cdot$ Joan A. Barberá ${ }^{2,5} \cdot$ Manuel Castellá $^{2} \cdot$ Manel Sabaté2 $^{2}$ \\ Valentín Fuster $^{1,8} \cdot$ Borja Ibañez ${ }^{1,9}$
}

Received: 5 August 2015/Accepted: 6 June 2016/Published online: 21 June 2016

(c) The Author(s) 2016. This article is published with open access at Springerlink.com

\begin{abstract}
Beta-3 adrenergic receptor ( $\beta 3 \mathrm{AR}$ ) agonists have been shown to produce vasodilation and prevention of ventricular remodeling in different conditions. Given that these biological functions are critical in pulmonary hypertension $(\mathrm{PH})$, we aimed to demonstrate a beneficial effect of $\beta 3 \mathrm{AR}$ agonists in $\mathrm{PH}$. An experimental study in pigs $(n=34)$ with chronic $\mathrm{PH}$ created by pulmonary vein banding was designed to evaluate the acute hemodynamic effect and the long-term effect of $\beta 3 \mathrm{AR}$ agonists on hemodynamics, vascular remodeling and RV performance in chronic $\mathrm{PH}$. Ex vivo human experiments were performed to explore the expression of $\beta 3 \mathrm{AR}$ mRNA and the vasodilator response of $\beta 3 \mathrm{AR}$
\end{abstract}

A. García-Álvarez and D. Pereda shared the same amount of work.

Ana García-Álvarez

agarciaa@cnic.es; anagarci@clinic.ub.es

$\triangle$ Borja Ibañez

bibanez@cnic.es

Centro Nacional de Investigaciones Cardiovasculares Carlos III (CNIC), Madrid, Spain

2 Hospital Clínic, IDIBAPS, Barcelona, Spain

3 Hospital Universitario Quirón Madrid, UEM, Madrid, Spain

4 Hospital Clínico San Carlos, Madrid, Spain

5 Centro de Investigación Biomédica en Red (CIBER) de Enfermedades Respiratorias, Barcelona, Spain

6 Hospital Universitario Montepríncipe, Madrid, Spain

7 Hospital Universitario Central de Asturias, Oviedo, Spain

8 Zena and Michael A. Wiener Cardiovascular Institute, Mount Sinai School of Medicine, New York, USA

9 Department of Cardiology, IIS-Fundación Jiménez Díaz, Madrid, Spain agonists in pulmonary arteries. Single intravenous administration of the $\beta 3$ AR agonist BRL37344 produced a significant acute reduction in PVR, and two-weeks treatment with two different $\beta 3 \mathrm{AR}$ selective agonists, intravenous BRL37344 or oral mirabegron, resulted in a significant reduction in PVR (median of -2.0 Wood units $/ \mathrm{m}^{2}$ for BRL37344 vs. +1.5 for vehicle, $p=0.04$; and -1.8 Wood units $/ \mathrm{m}^{2}$ for mirabegron vs. +1.6 for vehicle, $p=0.002$ ) associated with a significant improvement in magnetic resonance-measured RV performance. Histological markers of pulmonary vascular proliferation (p27 and Ki67) were significantly attenuated in $33 \mathrm{AR}$ agonists-treated pigs. $33 \mathrm{AR}$ was expressed in human pulmonary arteries and $\beta 3 \mathrm{AR}$ agonists produced vasodilatation. $\beta 3 \mathrm{AR}$ agonists produced a significant reduction in PVR and improved RV performance in experimental $\mathrm{PH}$, emerging as a potential novel approach for treating patients with chronic $\mathrm{PH}$.

Keywords Beta-3 adrenergic receptor - Pulmonary hypertension - Therapy $\cdot$ Pulmonary vascular resistance

$\begin{array}{ll}\text { Abbreviations } \\ \text { PVR } & \text { Pulmonary vascular resistance } \\ \text { PVRI } & \text { Pulmonary vascular resistance index } \\ \text { RV } & \text { Right ventricular } \\ \text { B3AR } & \text { Beta-3 adrenergic receptor } \\ \text { PH } & \text { Pulmonary hypertension } \\ \text { CMR } & \text { Cardiac magnetic resonance } \\ \text { PAP } & \text { Pulmonary arterial pressure } \\ \text { CI } & \text { Cardiac index } \\ \text { SBP } & \text { Systemic blood pressure } \\ \text { HR } & \text { Heart rate }\end{array}$




\section{Introduction}

Pulmonary hypertension $(\mathrm{PH})$ comprises a group of diseases characterized by a chronic increase in pulmonary arterial pressure (PAP) and pulmonary vascular resistance (PVR), and progressive right ventricular (RV) dysfunction [16]. Globally, prevalence of PH is high as it affects nearly $50 \%$ of patients with heart failure [37] or chronic obstructive pulmonary disease [1], and it is associated with a poor prognosis [21]. Few therapies are currently available for pulmonary arterial hypertension (group 1 in the current PH classification), but no pharmacological therapy has been demonstrated to have a consistent effect in $\mathrm{PH}$ due to left heart disease (group 2), which is the most frequent cause of $\mathrm{PH}[15,37]$. Right heart catheterization remains mandatory for the precise quantification of pulmonary hemodynamics [21] and, while diagnosis of PH is currently based on mean PAP, PVR provides a more consistent prognostic value in $\mathrm{PH}$ of different etiologies $[6,32]$.

Impairment of nitric oxide synthesis and signaling through the soluble guanylate cyclase-cyclic guanylate monophosphate pathway $[17,24]$ are implicated in the pathogenesis of $\mathrm{PH}$ causing vasoconstriction and structural remodeling. Therapies that increase nitric oxide release and guanylate cyclase-cyclic guanylate monophosphate availability, in addition to their vasodilator effect, have an antiproliferative effect on the pulmonary vasculature $[35,38]$.

Beta-3 adrenergic receptor ( $\beta 3 \mathrm{ARs}$ ) mRNA expression has been found in the human myocardium [23] and vessels [8], and it has been described to be upregulated in left heart disease [23], although convincing evidence of functional $\beta 3 A R s$ in the human heart is still a matter of debate [36]. Recently, several experimental studies have shown that in vivo treatment with BRL37344, a B3AR agonist, improves cardiac performance and ameliorates myocardial injury in experimental models of heart failure $[5,25]$ and ischemia-reperfusion $[2,14,26]$ through a nitric oxidemediated mechanism. In pulmonary vessels from dogs [33] and rats [10], ex vivo $\beta 3 \mathrm{AR}$ agonists produces vasodilatation. No studies evaluating the effect of $\beta 3 \mathrm{AR}$ in $\mathrm{PH}$ have been conducted.

We therefore, hypothesized that $\beta 3 \mathrm{AR}$ agonists may produce a beneficial effect on $\mathrm{PH}$ acting through vasodilatation, inhibition of vascular remodeling, and prevention of RV dysfunction, the hallmarks of $\mathrm{PH}$. To answer this hypothesis, we designed an experimental large-animal study (porcine model of PH by pulmonary vein banding) and ex vivo human experiments with the following objectives: (1) To evaluate the acute hemodynamic effect of $\beta 3 \mathrm{AR}$ agonists in chronic $\mathrm{PH}$; (2) To evaluate the long-term effect of $\beta 3 \mathrm{AR}$ agonists on pulmonary hemodynamics, RV performance, and pulmonary vascular remodeling in chronic $\mathrm{PH}$; and (3) To explore the expression of $\beta 3 \mathrm{AR}$ mRNA and the vasodilator response of $\beta 3 \mathrm{AR}$ agonists in human pulmonary arteries. This is the first study of a broad project aimed to evaluate the clinical relevance of this potential new therapy (current study) and the mechanisms of action (ongoing work).

\section{Methods}

\section{Large-animal study design and experimental model}

Experimental animal procedures were performed in a total of 34 castrated-male Large-White pigs. The study was approved by the Institutional Animal Research Committee and carried out in compliance with the Guide for the Care and Use of Laboratory Animals. Before any procedure, anesthesia was induced by intramuscular injection of ketamine $(20 \mathrm{mg} / \mathrm{kg})$, xylazine $(2 \mathrm{mg} / \mathrm{kg})$, and midazolam $(0.5 \mathrm{mg} / \mathrm{kg})$. Buprenorphine $(0.3 \mathrm{mg} / \mathrm{kg})$ was used for analgesia and animals were intubated.

\section{Pig model of chronic $\mathrm{PH}$}

A model of chronic post-capillary PH was generated by surgical banding of the main pulmonary vein (venous confluent arising from the junction of both inferior pulmonary veins) through a small thoracotomy in 4 week-old piglets (weigh $\approx 10 \mathrm{~kg}$ ), as previously described [28]. This procedure has demonstrated to generate progressive chronic PH that becomes stable from the third month [28], associated with typical PH changes on pathology.

Proof of concept of $\beta 3 A R$ agonists in chronic $P H$ As a proof of concept in chronic $\mathrm{PH}, 8$ pigs (3-month old and weighing $\approx 30 \mathrm{~kg}$ ) with previous pulmonary vein banding and confirmed chronic $\mathrm{PH}$ were used to evaluate the acute hemodynamic effect of $\beta 3 \mathrm{AR}$ agonists. For this aim, freebreathing pigs on room air received intravenously a dose of $5 \mu \mathrm{g} / \mathrm{kg}$ of BRL37344 under right heart catheterization, invasive systemic blood pressure (SBP) and electrocardiographic monitoring. Complete hemodynamic evaluation was repeated after $20 \mathrm{~min}$.

Long-term $\beta 3 A R$ agonist treatment in chronic $P H$ To evaluate the effect of long-term therapy with $\beta 3 \mathrm{AR}$ agonists in chronic $\mathrm{PH}$, two different experiments testing different $\beta 3 \mathrm{AR}$ selective agonists were conducted: (1) continuous intravenous treatment with the $\beta 3 \mathrm{AR}$ agonist BRL37344 $\left(R^{*}, R^{*}\right)$-( \pm )-4-[2-[(2-(3-Chlorophenyl)-2-hydroxyethyl) amino] propyl] phenoxyacetic acid, sodium 
salt) and (2) oral $\beta 3 \mathrm{AR}$ agonist mirabegron (Myrbetriq ${ }^{\circledR}$, Astellas Pharma US, Northbrook, IL, USA). An additional arm using nebivolol (Lobivon ${ }^{\circledR}$, Menarini, Luxembourg), a $\beta 1 \mathrm{AR}$ antagonist and $\beta 3 \mathrm{AR}$ agonist, was included in the second experiment to evaluate the effect of $\beta 3 \mathrm{AR}$ agonism with simultaneous $\beta 1 \mathrm{AR}$ blockade in chronic $\mathrm{PH}$.

On the first long-term experiment, 8 pigs (4-month old and weighing $\approx 45 \mathrm{~kg}$ ) with chronic $\mathrm{PH}$ were blindly randomized to receive a continuous intravenous infusion of BRL37344 or vehicle (saline) using osmotic pumps (Alzet $^{\circledR}$, DURECT Corp., Cupertino, CA, USA). For this purpose, we used $2 \mathrm{~mL}$ osmotic pumps with a pre-specified delivery rate of $5 \mu \mathrm{L} / \mathrm{h}$ during 14 days, and equipped with a polyethylene infusion catheter (polyethylene tubing PE60). Pumps contained either a dose of $10 \mu \mathrm{g} / \mathrm{kg} /$ day of BRL37344 dissolved in saline or vehicle (saline) and were surgically implanted with the catheter inserted in the right external jugular vein. Right heart catheterization and cardiac magnetic resonance (CMR) imaging were performed immediately before pump insertion and 14 days later.

For the second long-term experiment, another 18 pigs (4-month old and weighing $\approx 45 \mathrm{~kg}$ ) with chronic $\mathrm{PH}$ were blindly randomized to receive oral treatment with mirabegron (100 mg/day; $n=6$ ) or nebivolol ( $5 \mathrm{mg} /$ day; $n=6$ ) administered within an apple or vehicle (only the apple; $n=6$ ) for 14 days. Similarly, right heart catheterization and CMR imaging were performed immediately before initiation of treatment and 14 days later. In both experiments, only a veterinarian not involved in the study knew treatment allocation.

\section{Invasive hemodynamic assessment}

SBP was monitored with a femoral arterial cannula (Arrow, Reading, PA, USA). Right heart catheterization was performed using a Swan-Ganz catheter (Braun, Kronberg, Germany) inserted through the femoral vein and positioned under fluoroscopy to measure PAP and cardiac output as assessed by the thermodilution method. PVR was calculated as the difference between mean PAP and left ventricular end-diastolic pressure quantified with a pigtail catheter divided by the cardiac output in Wood units. Cardiac output and PVR were indexed by body surface area estimated by the Brody's formula [4].

\section{CMR studies}

All CMR studies were performed with a $3.0 \mathrm{~T}$ magnet (Achieva-Tx, Philips Medical Systems, The Netherlands), equipped with a 32-channel cardiac phased-array surface coil and retrospective electrocardiographic gating during spontaneous ventilation. Steady-state free precession cine sequences were acquired in 10-15 contiguous short axis slices covering both ventricles from base to apex with 30 cardiac phases each for the evaluation of ventricular volumes and function. Two-dimensional flow imaging (phasecontrast) was performed perpendicular to the main pulmonary artery with a velocity-encoded gradient echo sequence using the minimum upper velocity limit without signal aliasing, as previously described [13].

Analysis of CMR acquisitions was performed using specialized software (Extended MR Workspace ${ }^{\circledR}$, Philips Healthcare, The Netherlands). Observers were blinded to the study arm, experimental allocation ( $\beta 3 \mathrm{AR}$ agonist/vehicle) and hemodynamic measurements. On cine images, biventricular endocardial contours were manually traced in end-diastole and end-systole and Simpson's method was used to calculate volumes and ejection fraction. RV trabeculations were included within the blood pool and the interventricular septum was adjudicated to the left ventricular mass. Similarly, the inner contour of the main pulmonary artery was outlined in each cardiac phase to quantify the minimum and maximum areas, average pulmonary artery velocity, and RV stroke volume. Ventricular volumes and masses and pulmonary artery areas were similarly adjusted to body surface area.

\section{Histological studies}

\section{Pig samples}

At the completion of the study, animals with chronic $\mathrm{PH}$ randomized to the oral $\beta 3 \mathrm{AR}$ agonist mirabegron or vehicle were euthanized with a lethal injection of pentobarbital sodium and the lung parenchyma was excised for histological evaluation. Expression of P27 and Ki67 was compared between groups to assess differences in cell proliferation in pulmonary arteries within lung parenchyma.

Western blot for P27 expression Randomly chosen lower lobe pulmonary parenchyma portions were snap frozen in liquid nitrogen and stored at $-80{ }^{\circ} \mathrm{C}$ until used. For protein isolation, samples were homogenized using a radio-immunoprecipitation assay lysis buffer $(150 \mathrm{mmol} / \mathrm{L} \mathrm{NaCl}$, $1.0 \%$ IGEPAL, $0.5 \%$ sodium deoxycholate, $0.1 \%$ SDS, $50 \mathrm{mmol} / \mathrm{L}$ Tris, $\mathrm{pH}$ 8.0) supplemented with protease/ phosphatase inhibitors. After quantification (Pierce BCA Protein Assay Kit, Pierce Biotechnology, Rockford, IL, USA), $50 \mu \mathrm{g}$ of proteins were loaded in $15 \%$ sodium dodecyl sulfate polyacrylamide gels. Proteins were transferred into a polyvinylidene fluoride membrane following electrophoresis and incubated with the primary specific antibody for p27 (BD Biosciences, Santa Fe, CA, USA) overnight in Tris Buffer Saline $+0.1 \%$ Tween $+5 \%$ Bovine Serum Albumin. Total ERK 1-2 (Cell Signaling, Danver, MA, USA) protein was used as loading control. 
Blots were developed by chemiluminescence after HRPsecondary antibody, 1-hour incubation using Luminata Forte substrate (EMD Millipore, Billerica, MA, USA). Intensity of the bands was analyzed using the ImageJ 6.0 software (NIH, Bethesda, MD, USA) and the ratio between p27 and total ERK 1-2 protein was calculated in densitometry units.

Immunohistochemical staining for Ki67 expression Randomly chosen lower lobe pulmonary parenchyma portions were fixed in $4 \%$ paraformaldehyde for $48 \mathrm{~h}$, dehydrated and embedded in paraffin. Specific staining for Ki67 (Master Diagnostica, Granada, Spain) and haematoxylin was performed in $4 \mu \mathrm{m}$ sections. An average size of $200 \mathrm{~mm}^{2}$ for each parenchyma was digitalized using the NanoZoomer 20RS scanner (Hamamatsu Photonics K.K., Hamamatsu, Japan) at a magnification of 40x. The quantification of the positive Ki67 nuclei in the wall of the arteries was performed in the digitalized images using the NanoZoomer digital Pathology viewer (Hamamatsu Photonics K.K., Hamamatsu, Japan). A number of 24 arteries with a diameter between 30 and $100 \mu \mathrm{m}$ were quantified per subject and the results represented as median (interquartile range) of Ki67 positive nuclei per artery (wall) and also adjusted by the arterial diameter.

\section{Human samples}

Human pulmonary artery smooth muscle cell cultures Human pulmonary artery smooth muscle cells were purchased from ScienCell Research Laboratories (Carlsbad, CA, US) and cultured in a specific medium (Sciencell No. 1101, Carlsbad, CA, US) supplemented with $2 \%$ fetal bovine serum $100 \mathrm{U} / \mathrm{mL}$ penicillin, $100 \mu \mathrm{g} / \mathrm{mL}$ streptomycin, and $1 \%$ smooth muscle cells growth supplement (Sciencell No. 1152, Carlsbad, CA, USA) in a humidified incubator with a constant supply of $5 \% \mathrm{CO}_{2}$ at $37{ }^{\circ} \mathrm{C}$ to be used for experiments at passages 3-7.

Human pulmonary artery smooth muscle cells were seeded in gelatin $0.1 \%$ coated 48 -well plates (same number per well) and starved in medium with $0.4 \%$ FBS for $24 \mathrm{~h}$ and then incubated under either normoxic or hypoxic $\left(3 \% \mathrm{O}_{2}, 5 \% \mathrm{CO}_{2}\right.$ at $\left.37{ }^{\circ} \mathrm{C}\right)$ conditions for $72 \mathrm{~h}$. For treatment, cells were co-incubated with BRL37344 $(0.001 \mu \mathrm{M})$ alone or associated with NG-nitro-L-arginine methyl ester (L-NAME 10 mM, Sigma-Aldrich Co. LLC.) during the hypoxia exposure. Human pulmonary artery smooth muscle cells proliferation was determined by cell counting using flow cytometry. All experiments were performed in triplicate.

RNA isolation and cDNA synthesis Collection of human main pulmonary arteries and lung samples was carried out at Hospital Clínic (Barcelona). The Ethics Committee of this Institution approved the research protocol and all patients gave informed consent. Main pulmonary artery samples were obtained from patients undergoing elective heart transplantation ( $n=10$, urgent cases were excluded). No patient received sympathomimetic drugs in days before transplantation. Main pulmonary artery tissue was homogenized and RNA was extracted using RNeasy Mini Kit (Qiagen, Valencia, CA, USA) according to manufacturer's instructions.

RNA was quantified by measurement of optical density at $260 \mathrm{~nm}$ using the spectrophotometer Nanodrop ND1000 (ThermoScientific, Wilmington, DE, USA) and frozen at $-80{ }^{\circ} \mathrm{C}$ until their usage. A total of $1 \mu \mathrm{g}$ of RNA were taken to perform Reverse Transcriptase using Illustra Ready-to-go RT-PCR Beads kit (GE Healthcare Bio-sciences, Pittsburgh, PA, USA) according to manufacturer's instructions. A final volume of $50 \mu \mathrm{L}$ was incubated at $42{ }^{\circ} \mathrm{C}$ for $30 \mathrm{~min}$ followed by $5 \mathrm{~min}$ at $95{ }^{\circ} \mathrm{C}$.

Real-time quantitative RT-PCR G0ene expressions assay was performed using the ABI PRISM ${ }^{\circledR} 7900$ HT FAST Real-Time PCR System (Life Technologies, Carlsbad, CA, USA). A $10 \mu \mathrm{L}$ of real-time PCR reaction Power SYBR Green PCR Master Mix (Life Technologies, Carlsbad, CA, USA) was used following manufacturer's instructions. Sequences of the primers were as follow: for $h \beta 3 A R$, 5'-ACCTTCCTCTTCTCGTGATGC-3' (sense) and 5'-GG CGGAGACTCCTCGGG-3' (antisense); and for the housekeeping gene 18S, 5'-AGTTGGTGGAGCGATTTG-3' (sense) and 5'-TTGCTCAATCTCGGTGG-3'. They were designed using human GenBank and Basic Local Alignment Search Tool (BLAST; NCBI). The following temperature-time profile was used to perform the real-time PCR: pre-incubation at $95{ }^{\circ} \mathrm{C}$ for $10 \mathrm{~min}, 40$ cycles for amplification of the targets and controls cDNA consisting of denaturation at $95{ }^{\circ} \mathrm{C}$ for $15 \mathrm{~s}$; annealing and extension at $60{ }^{\circ} \mathrm{C}$ for $60 \mathrm{~s}$. Specific amplification was confirmed by the presence of a single peak in the melting curve plots. PCR products were electrophoretically separated in a $3 \%$ agarose gel to confirm the 105 base pair amplicon product.

\section{Organ bath studies}

Organ bath studies were performed to evaluate the vasodilator effect of BRL37344 in small human pulmonary arteries accordingly with previous methodology [27]. Briefly lung samples were obtained from patients $(n=10)$ undergoing lobectomy or pneumonectomy after informed consent. In the laboratory, $2 \mathrm{~mm}$-diameter arteries were cleaned of fat and connective tissue and cut into rings (3 mm long). Rings were suspended on stainless-steel wires in an organ bath containing Krebs solution. The 
temperature of the bath was maintained at $37 \pm 0.5^{\circ} \mathrm{C}$ and the Krebs solution was continuously oxygenated with a $21 \% \mathrm{O}_{2}, 5 \% \mathrm{CO}_{2}$ and rest nitrogen mixture. Arterial rings were progressively stretched to a stable resting tension of $1.75 \mathrm{~g}$. Isometric tension was recorded using a force displacement transducer (PanLab, Barcelona, Spain) and displayed on a computer. After a $2 \mathrm{~h}$ equilibration period, with the Krebs solution being changed every $15 \mathrm{~min}$, the rings were contracted with norepinephrine $\left(1 \times 10^{-7}\right.$ $\left.1 \times 10^{-6} \mathrm{~mol} / \mathrm{L}\right)$. Once the contraction reached a plateau, cumulative concentration-response curves to BRL37344 $\left(1 \times 10^{-8}-1 \times 10^{-4} \mathrm{~mol} / \mathrm{L}\right)$ were constructed. The relaxation produced by each concentration was measured after a steady-state was reached. Values were expressed as the percentage change in the maximal tension of rings after addition of norepinephrine.

\section{Determination of BRL37344, mirabegron and nebivolol in plasma}

Plasma concentrations of BRL37344, mirabegron and nebivolol were determined by LC-MS/MS method in three different pigs 4 and $6 \mathrm{~h}$ after implantation of BRL37344 pump or first mirabegron or nebivolol dose, and everyday before daily dose administration during 1 week.

At scheduled time points, $2 \mathrm{~mL}$ blood samples were taken via venipuncture and collected into tubes containing heparin as an anticoagulant. Following blood sampling, sample tubes were centrifuged at $1500 \mathrm{rpm}$ and $4{ }^{\circ} \mathrm{C}$ during $20 \mathrm{~min}$. The separated plasma was immediately stored at $-70{ }^{\circ} \mathrm{C}$ till analysis. Before analysis, ammonium acetate (20 $\mathrm{mmol} / \mathrm{L}$ ) and acetic acid were added to the plasma to get a $\mathrm{pH}$ around 5. Then the samples were lyophilized. Lyophilized plasma was re-suspended in methanol (same amount) and centrifuged at $13,400 \mathrm{rpm}$ for $15 \mathrm{~min}$. The upper organic layer was injected into the LC-MS/MS system.

\section{Statistical analysis}

Continuous variables are expressed as median (interquartile range), otherwise specified. Given the small sample sizes, all variables were considered as non-normally distributed. Mann-Whitney $U$ test was used to compare baseline continuous variables between groups, and to evaluate whether the change in the outcome variables from pre to post-treatment differed between two groups. Differences were considered statistically significant at $p$ value $<0.05$. Analyses were performed with SPSS version 20 (IBM Corp., Armonk, New York).

\section{Results}

\section{Effect of B3AR agonists on hemodynamics and RV performance in experimental chronic $\mathbf{P H}$}

Proof of concept study In chronic PH $[n=8$, mean PAP 37.5 (17.0), PVRI 7.6 (7.7)], a single bolus of BRL37344 $(5 \mu \mathrm{g} / \mathrm{kg})$ caused, $20 \mathrm{~min}$ after intervention, a significant reduction in PAP and PVRI associated with an increase in CI (Table 1).

Long-term studies In the first experiment $[n=8$, mean PAP 32.5 (8.8), PVRI 5.7 (4.0)], animals randomized to long-term intravenous therapy with the $\beta 3 \mathrm{AR}$ agonist BRL37344 (10 $\mu \mathrm{g} / \mathrm{kg} /$ day for 14 days) showed a significant reduction in PVRI and an increase in CI compared with vehicle (Table 2; Fig. 1a).

Comparable results were observed in the second experiment $[N=18$, mean PAP 37.5 (8.3) mmHg, PVRI 6.4 (2.1) Wood units $/ \mathrm{m}^{2}$ ]. Animals randomized to longterm oral treatment with the oral $\beta 3 \mathrm{AR}$ agonist mirabegron $(100 \mathrm{mg} /$ day for 14 days) showed a significant reduction in PVRI and an increase in CI compared with vehicle (Table 3; Fig. 1b). Finally, animals randomized to nebivolol (oral $\beta 3 \mathrm{AR}$ agonist and $\beta 1 \mathrm{AR}$ antagonist) showed a significant reduction in PVRI as well, without significant change in cardiac index (Table 3; Fig. 1c).

Chronic therapy with selective $\beta 3 \mathrm{AR}$ agonist [BRL37344 $(n=4)$ or mirabegron $(n=6)$ ] was associated with improved RV performance on CMR evaluation as compared with placebo $(n=10)$. Two weeks after treatment, there were significant differences in the change in RV systolic volume and RV ejection fraction (Table 4). In addition, a significant increase in average pulmonary artery velocity in the $\beta 3 \mathrm{AR}$-treated group was observed, a surrogate non-invasive measurement of PVR [13].

\section{Effect of B3AR agonists on p27 and Ki67 expression in lungs from chronic $\mathbf{P H}$ pigs}

Pigs with chronic $\mathrm{PH}$ treated with the oral $\beta 3 \mathrm{AR}$ agonist mirabegron showed a significant increase in p27 protein levels as compared with the controls (Fig. 2a). The density of Ki67 positive cells was lower in pulmonary arteries from $\mathrm{PH}$ pigs treated with mirabegron compared with those treated with the vehicle alone [3 (2) vs. 1 (2) cells/artery, $p<0.01)$. Similar results were obtained after adjusting with the arterial diameter [3.5 (2.4) vs. 2.2 (2.6) cells/ artery $\left./ \mu \mathrm{m} \times 10^{2}, p<0.01\right)$ or whether analyzed as a categorical variable (Fig. 2b). 
Table 1 Acute hemodynamic effect of $\beta 3$ AR agonist treatment using BRL37344 in chronic PH

\begin{tabular}{|c|c|c|c|c|}
\hline & Baseline $(N=8)$ & 20 min after BRL37344 $(N=8)$ & Change & $p$ \\
\hline Weight (kg) & $33.0(17.5)$ & NA & NA & NA \\
\hline $\mathrm{SpO}_{2}(\%)$ & $90.5(2.0)$ & $93.0(3.0)$ & $3.0(2.75)$ & 0.011 \\
\hline HR (bpm) & $91.0(39.0)$ & $93.0(30.0)$ & $-6.0(14.0)$ & 0.199 \\
\hline Systolic BP (mmHg) & $113.5(30.0)$ & $105.0(31.0)$ & $-8.0(12.75)$ & 0.058 \\
\hline Diastolic BP (mmHg) & $70.5(17.0)$ & $63.0(3.0)$ & $-9.0(18.0)$ & 0.063 \\
\hline Mean BP (mmHg) & $90.5(23.0)$ & $80.0(15.0)$ & $10.0(8.75)$ & 0.109 \\
\hline Systolic PAP (mmHg) & $51.0(20.0)$ & $38.0(15.0)$ & $-12.0(13.25)$ & 0.002 \\
\hline Diastolic PAP (mmHg) & $27.0(15.0)$ & $17.0(12.0)$ & $-6.0(5.5)$ & $<0.001$ \\
\hline Mean PAP (mmHg) & $37.5(17.0)$ & $26.0(12.0)$ & $-9.0(6.0)$ & $<0.001$ \\
\hline Cardiac index $\left(\mathrm{L} / \mathrm{min} / \mathrm{m}^{2}\right)$ & $4.0(1.2)$ & $4.7(1.1)$ & $0.33(1.48)$ & 0.018 \\
\hline PVRI $\left(\mathrm{WU} / \mathrm{m}^{2}\right)$ & $7.6(7.7)$ & $3.9(6.9)$ & $-2.5(3.6)$ & 0.006 \\
\hline
\end{tabular}

Values are expressed as median (interquartile range)

$\mathrm{SpO}_{2}$ oxygen saturation by pulse oximetry, $H R$ heart rate, $b p m$ beats per minute, $B P$ blood pressure, $P A P$ pulmonary artery pressure, $P V R I$ pulmonary vascular resistance index, $W U$ wood units

Table 2 Long-term effect of continuous intravenous B3AR treatment with BRL37344 on hemodynamics in chronic PH

\begin{tabular}{|c|c|c|c|c|c|c|c|}
\hline & \multicolumn{2}{|l|}{ Baseline } & \multicolumn{2}{|c|}{ Post-treatment } & \multicolumn{3}{|c|}{ Change 14 days after intervention } \\
\hline & $\begin{array}{l}\text { Vehicle } \\
(N=4)\end{array}$ & $\begin{array}{l}\text { BRL37344 } \\
(N=4)\end{array}$ & $\begin{array}{l}\text { Vehicle } \\
(N=4)\end{array}$ & $\begin{array}{l}\text { BRL37344 } \\
(N=4)\end{array}$ & $\begin{array}{l}\text { Vehicle } \\
(N=4)\end{array}$ & $\begin{array}{l}\text { BRL37344 } \\
(N=4)\end{array}$ & $p$ \\
\hline Weight (kg) & $43.8(20.6)$ & $50.8(19.3)$ & $57.8(22.8)$ & $64.0(26.9)$ & $13.5(5.1)$ & $12.8(8.1)$ & 0.644 \\
\hline $\mathrm{SpO}_{2}(\%)$ & $95.0(3.0)$ & $92.5(9.0)$ & $92.0(4.0)$ & $88.5(7.0)$ & $-3.5(4.0)$ & $-1.5(9.0)$ & 0.715 \\
\hline HR (bpm) & $73.0(15.0)$ & $72.5(14.0)$ & $77.5(47.0)$ & $84.0(23.0)$ & $0.5(53.7)$ & $15.0(18.3)$ & 0.535 \\
\hline Systolic BP (mmHg) & $113.5(21.0)$ & $120.0(21.0)$ & $118.0(22.0)$ & $113.5(11.0)$ & $9.5(10.8)$ & $-4.5(11.5)$ & 0.034 \\
\hline Diastolic BP (mmHg) & $76.0(17.0)$ & $74.5(6.0)$ & $71.0(28.0)$ & $74.5(8.0)$ & $-1.5(16.3)$ & $4.0(7.8)$ & 0.773 \\
\hline Mean BP (mmHg) & $93.0(20.0)$ & $94.0(13.0)$ & $93.5(24.0)$ & $91.0(8.0)$ & $5.0(12.8)$ & $-0.5(9.0)$ & 0.219 \\
\hline Systolic PAP (mmHg) & $38.0(25.5)$ & $46.5(13.5)$ & $45.8(20.8)$ & $40.8(10.0)$ & $3.3(11.4)$ & $-4.5(12.0)$ & 0.167 \\
\hline Diastolic PAP (mmHg) & $23.0(8.3)$ & $25.5(6.3)$ & $30.0(16.5)$ & $25.8(8.4)$ & $6.0(13.3)$ & $1.8(11.4)$ & 0.501 \\
\hline Mean PAP (mmHg) & $29.5(13.0)$ & $36.0(8.0)$ & $38.3(18.9)$ & $32.2(7.9)$ & $5.8(11.9)$ & $-0.8(9.9)$ & 0.185 \\
\hline Cardiac index $\left(\mathrm{L} / \mathrm{min} / \mathrm{m}^{2}\right)$ & $4.4(1.0)$ & $4.5(1.5)$ & $4.4(1.4)$ & $5.3(2.0)$ & $-0.4(1.5)$ & $0.9(0.6)$ & 0.042 \\
\hline $\begin{array}{l}\text { LV End-diastolic pressure } \\
(\mathrm{mmHg})\end{array}$ & $8.5(3.0)$ & $6.5(3.0)$ & $9.5(8.0)$ & $9.0(2.0)$ & $1.0(5.8)$ & $2.0(2.8)$ & 0.775 \\
\hline PVRI (WU/m²) & $4.9(4.2)$ & $6.5(3.6)$ & $6.4(8.1)$ & $4.4(2.7)$ & $1.5(4.1)$ & $-2.0(2.7)$ & 0.040 \\
\hline
\end{tabular}

Values are expressed as median (interquartile range)

$\mathrm{SpO}_{2}$ oxygen saturation by pulse oximetry, $H R$ heart rate, $b p m$ beats per minute, $B P$ blood pressure, $P A P$ pulmonary artery pressure, $P V R I$ pulmonary vascular resistance index, $W U$ wood units

\section{Effect of B3AR agonist on human hypoxia-induced pulmonary artery smooth muscle cell proliferation}

Hypoxia $(72 \mathrm{~h}, 3 \%)$ induced increased proliferation of human pulmonary artery smooth muscle cells that was inhibited by BRL37344. Co-incubation with L-NAME abolished the inhibitory effect of BRL37344 over proliferation (Fig. 3a).

\section{Detection of $\beta 3 A R$ mRNA expression in human pulmonary arteries and vasodilator effect of BRL37344}

We detected mRNA expression of $\mathrm{h} \beta 3 \mathrm{AR}$ in all human pulmonary arteries by qPCR. The amplification curves for the human h $\beta 3 A \mathrm{AR}$ and the human $18 \mathrm{~s}$ are shown in Fig. $3 b$. 

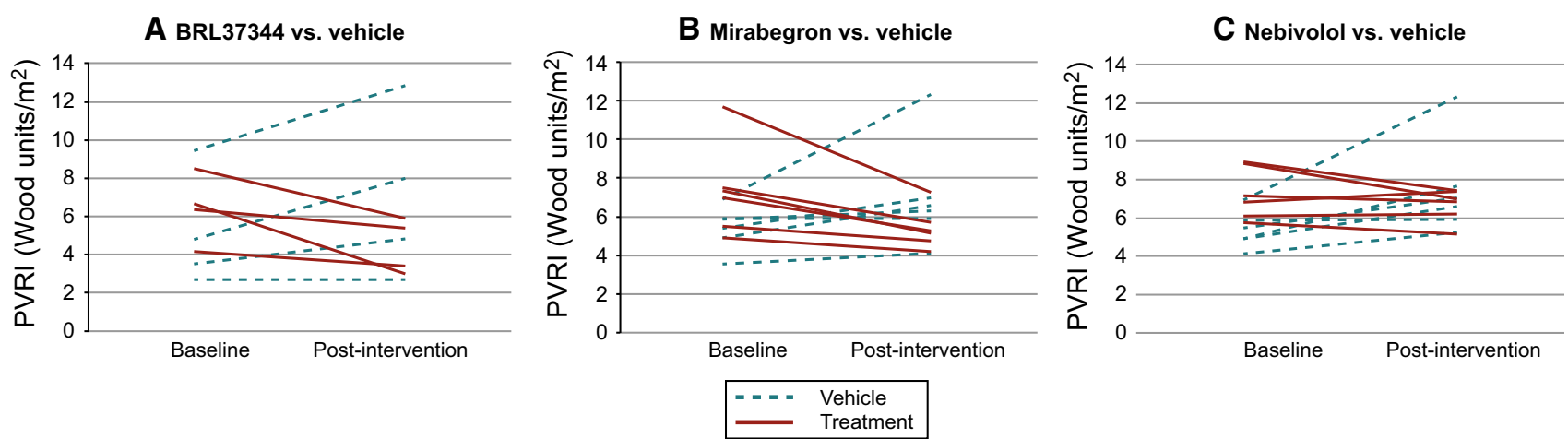

Fig. 1 Effect of $\beta 3$ AR stimulation vs. vehicle on PVRI in chronic PH. Individual data are shown in the first row whereas boxplots by intervention groups are shown in the second row

BRL37344 induced a dose-dependent relaxation in norepinephrin-precontracted human pulmonary artery rings (maximal relaxation of $51.0 \pm 7.7 \%$ achieved at $10^{-4} \mathrm{M}$, with maximal $\mathrm{NE}$ response of 18,495 (3420) $\mathrm{mN}$.) (Fig. 3c).

\section{Plasma concentrations of BRL37344, mirabegron and nebivolol}

Plasma concentration of BRL37344 was 1.37 and $5.15 \mathrm{ng} /$ $\mathrm{mL}$ at 4 and $6 \mathrm{~h}$ after pump implantation, respectively. Levels remained stable around $1 \mathrm{ng} / \mathrm{mL}(0.28-0.97)$ on daily analyses during 7 days.

Plasma concentration of mirabegron was 0.4 and $2.82 \mathrm{ng} / \mathrm{mL}$ at 4 and $6 \mathrm{~h}$ after administration. Levels remained stable around $1 \mathrm{ng} / \mathrm{mL}(0.7-1.5)$ on daily predose analyses during 7 days.

Plasma concentration of nebivolol was 0.14 and $0.08 \mathrm{ng} / \mathrm{mL}$ at 4 and $6 \mathrm{~h}$ after administration. Levels remained stable ranging between 0.05 and $0.06 \mathrm{ng} / \mathrm{mL}$ on daily pre-dose analyses during 7 days.

\section{Discussion}

This study represents the first evidence of the beneficial effects of $\beta 3 \mathrm{AR}$ agonists in $\mathrm{PH}$. The main findings of the study are: (1) Treatment with $\beta 3$ AR agonists reduces PVRI and improves RV performance in an experimental largeanimal translational model of chronic PH; (2) In lung tissue, long-term therapy with a $\beta 3 \mathrm{AR}$ agonist is associated with changes in protein expression suggestive of attenuated vascular proliferation; and (3) $\beta 3 \mathrm{AR}$ is expressed in human pulmonary arteries and $\beta 3 \mathrm{AR}$ agonist administration inhibits human pulmonary artery smooth muscle cell proliferation by a nitric oxide dependent mechanism and produces vasodilatation ex vivo.
$\mathrm{PH}$ is a prevalent and serious condition characterized by increased PAP and PVR and progressive RV dysfunction. In the present study, we demonstrated that treatment with $\beta 3 \mathrm{AR}$ agonists reduces PVRI and increases CI in translational experimental large-animal models of acute and chronic $\mathrm{PH}$, as assessed with right heart catheterization (the gold-standard technique). No significant changes were observed in SBP and HR, although the study may have been underpowered to detect differences in HR, parameter with high individual variability. A reduction in PVR with increased cardiac output demonstrated a vasodilator effect. The increase in cardiac output might be secondary to a reduction in afterload or a direct effect over the damaged $\mathrm{RV}$, as observed in the LV [5]. It has been repeatedly shown that PVR provides a more consistent prognostic value than mean PAP in $\mathrm{PH}$ of different etiologies $[6,32]$. Additionally, in advanced stages of chronic $\mathrm{PH}$, progressive RV failure can be accompanied by a decrease in PAP, whereas PVR continues to increase. In the specific case of $\mathrm{PH}$ associated with end-stage left heart disease, PVR is of paramount importance when deciding whether a patient might still be a candidate for heart transplantation [22].

There are two major classes of high-affinity $\beta 3 \mathrm{ARs}$ agonists, the phenylethanolamines that comprises BRL37344 and others, and the aryloxypropanolamines where mirabegron is included. Unlike BRL37344, mirabegron is available as oral tablet with extended release. Thereby, the second experiment of long-term therapy using mirabegron was performed to make the project and its results more translational since it would be potentially easier to treat patients with an oral $\beta 3 \mathrm{AR}$ agonist, which is, in addition, already approved for human use to treat hyperactive bladder syndrome (50 mg/day) [7]. The pharmacokinetic profile of mirabegron after single and multiple oral doses has been already reported in several cohorts of Caucasian [11, 19] and Asian adult subjects [18]. All have demonstrated that mirabegron plasma concentrations 


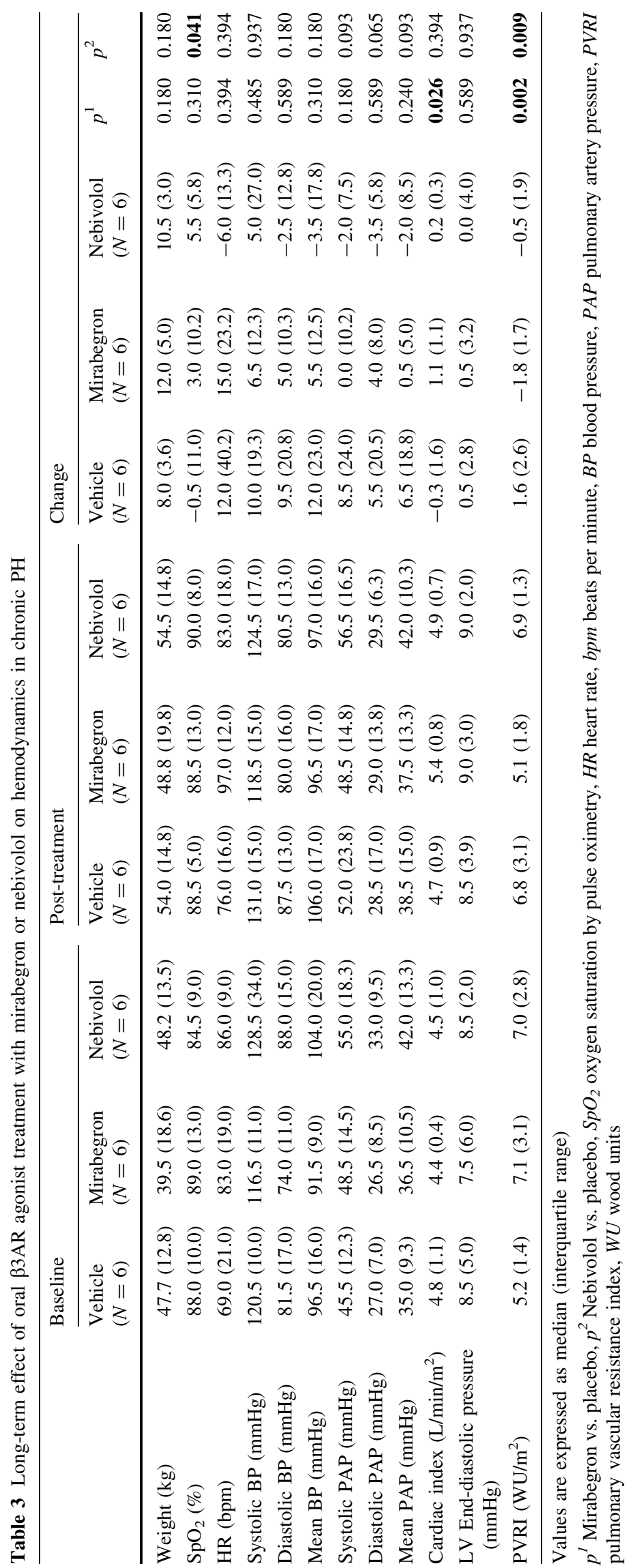


Table 4 Long-term effect of selective $\beta 3$ AR agonist treatment with BRL37344 or mirabegron on CMR parameters in chronic PH

\begin{tabular}{|c|c|c|c|c|c|c|c|}
\hline & \multicolumn{2}{|l|}{ Baseline } & \multicolumn{2}{|c|}{ Post-treatment } & \multicolumn{3}{|l|}{ Change } \\
\hline & $\begin{array}{l}\text { Vehicle } \\
(N=10)\end{array}$ & $\begin{array}{l}\beta 3 \mathrm{AR} \text { agonist } \\
(N=10)\end{array}$ & $\begin{array}{l}\text { Vehicle } \\
(N=10)\end{array}$ & $\begin{array}{l}\beta 3 \mathrm{AR} \text { agonist } \\
(N=10)\end{array}$ & $\begin{array}{l}\text { Vehicle } \\
(N=10)\end{array}$ & $\begin{array}{l}\beta 3 \mathrm{AR} \text { agonist } \\
(N=10)\end{array}$ & $p$ \\
\hline Weight (kg) & $47.2(12.3)$ & $42.7(18.6)$ & $57.3(13.6)$ & $54.0(24.3)$ & $10.2(5.7)$ & $12.0(5.4)$ & 0.481 \\
\hline HR (bpm) & $67.5(33.0)$ & $79.0(28.0)$ & $73.0(22.0)$ & $85.5(14.0)$ & $4.5(37.5)$ & $15.0(18.2)$ & 0.631 \\
\hline $\mathrm{RV}$ end-diastolic volume index $\left(\mathrm{ml} / \mathrm{m}^{2}\right)$ & $99.3(20.6)$ & $104.0(15.5)$ & $101.4(16.5)$ & $92.2(16.8)$ & $3.6(18.2)$ & $-4.0(26.1)$ & 0.143 \\
\hline $\mathrm{RV}$ end-systolic volume index $\left(\mathrm{ml} / \mathrm{m}^{2}\right)$ & $37.9(18.4)$ & $46.6(16.1)$ & $43.7(5.3)$ & $39.7(7.0)$ & $6.5(15.7)$ & $-5.4(9.8)$ & 0.009 \\
\hline LV end-diastolic volume index $\left(\mathrm{ml} / \mathrm{m}^{2}\right)$ & $97.1(9.5)$ & $90.3(17.7)$ & $93.2(11.8)$ & $93.3(17.3)$ & $-1.4(16.4)$ & $3.4(11.3)$ & 0.436 \\
\hline LV end-systolic volume index $\left(\mathrm{ml} / \mathrm{m}^{2}\right)$ & $35.5(11.0)$ & $36.2(9.0)$ & $37.5(8.7)$ & $37.2(11.6)$ & $1.0(7.7)$ & $1.0(7.7)$ & 0.971 \\
\hline RV mass index $\left(\mathrm{g} / \mathrm{m}^{2}\right)$ & $28.1(8.1)$ & $26.6(7.6)$ & $28.1(8.2)$ & $27.6(3.6)$ & $0.0(8.3)$ & $1.9(8.3)$ & 0.796 \\
\hline LV mass index $\left(\mathrm{g} / \mathrm{m}^{2}\right)$ & 58.8 (11.4) & $52.6(9.1)$ & $62.1(7.0)$ & $60.1(8.3)$ & $-2.1(17.6)$ & $7.3(15.8)$ & 0.247 \\
\hline RV ejection fraction (\%) & $61.9(13.0)$ & $52.0(6.4)$ & $56.4(5.6)$ & $58.4(7.8)$ & $-3.6(9.3)$ & $5.0(5.2)$ & 0.007 \\
\hline LV ejection fraction (\%) & $63.5(4.2)$ & $59.8(6.1)$ & $61.9(6.3)$ & $61.2(6.39$ & $-1.0(4.6)$ & $0.6(6.3)$ & 0.280 \\
\hline PA average velocity $(\mathrm{m} / \mathrm{s})$ & $11.0(3.3)$ & $10.5(4.9)$ & 11.7 (3.7) & $12.3(3.2)$ & $0.9(2.7)$ & $1.9(2.5)$ & 0.019 \\
\hline PA maximal area $\left(\mathrm{cm}^{2}\right)$ & $7.0(1.7)$ & $7.8(3.6)$ & $7.0(2.9)$ & $7.5(2.9)$ & $-0.3(1.7)$ & $-0.6(1.5)$ & 0.089 \\
\hline PA minimal area $\left(\mathrm{cm}^{2}\right)$ & $4.9(2.2)$ & $5.9(3.2)$ & $5.3(2.4)$ & $5.7(2.4)$ & $0.4(1.5)$ & $-0.3(2.1)$ & 0.075 \\
\hline
\end{tabular}

Values are expressed as median (interquartile range)

$H R$ heart rate, $b p m$ beats per minute, $R V$ right ventricular, $L V$ left ventricular, $P A$ pulmonary artery, $p^{l} p$ value from Student's $t$ test or MannWhitney $U$ test, as adequate; $p^{2} p$ value for the time*group interaction term in the repeated measures ANOVA or Mann-Whitney $U$ test of changes, as adequate

A

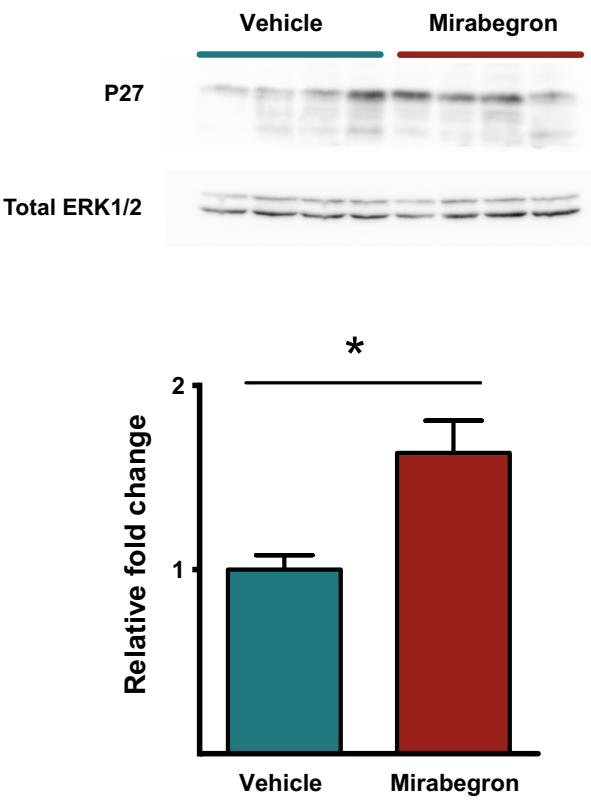

Fig. 2 Protein expression related with pulmonary cellular proliferation. a Western blot for the P27 protein in the lung parenchyma from pigs with chronic $\mathrm{PH}$ receiving vehicle $(N=4)$ or mirabegron $(N=4)$ for 14 days. The densitometric analysis of P27 normalized to total ERK $1 / 2$ is shown below. b Representative immunohistochemical pictures for Ki67 staining in pulmonary arteries within the lung parenchyma from sham-operated controls, pigs with chronic $\mathrm{PH}$
B
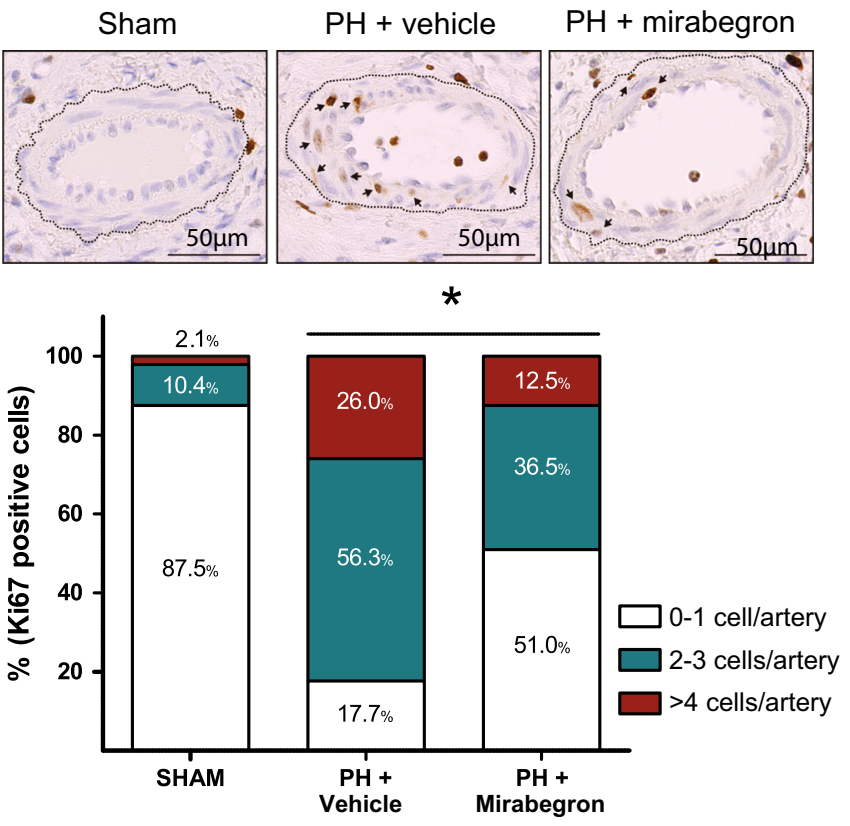

treated with vehicle and pigs with chronic $\mathrm{PH}$ treated with mirabegron. Brown staining indicates Ki67-positive cells. Arrows indicate Ki67-positive cells within the arterial wall. The frequency bar chart shown below represents the percentage of pulmonary arteries with Ki67 positive cells categorized in three groups $(0-1$ positive cell/artery, $2-3$ positive cells/artery and $>4$ positive cells per artery) by group. *Statistically significant differences 
A

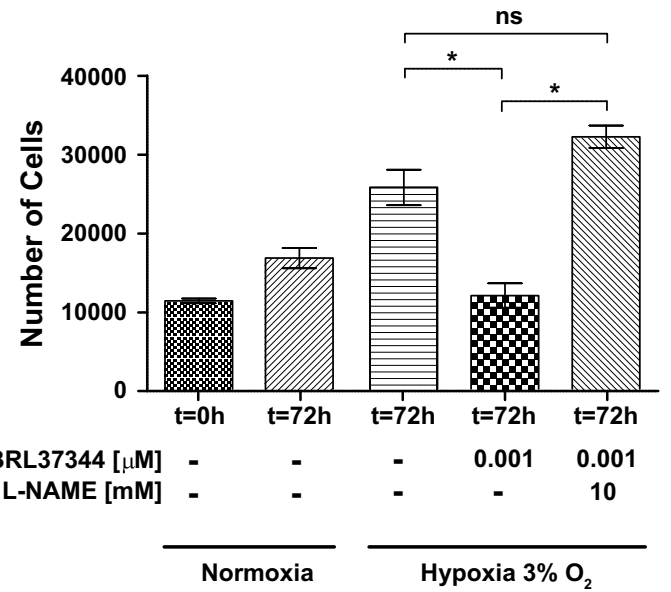

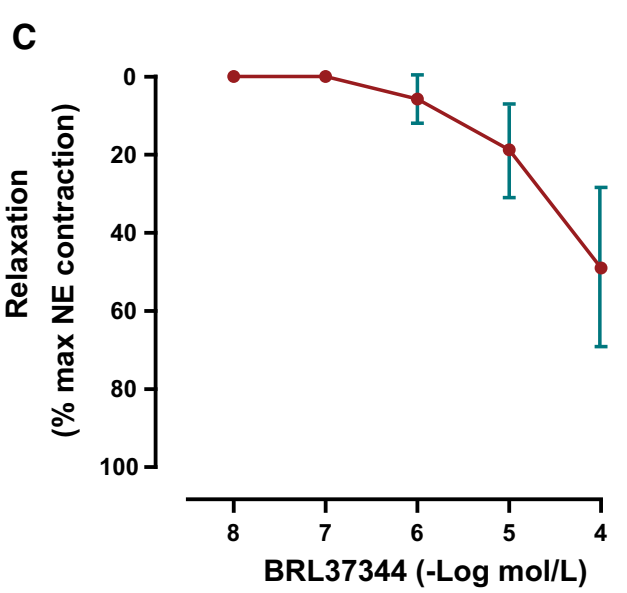

B

Amplification plot

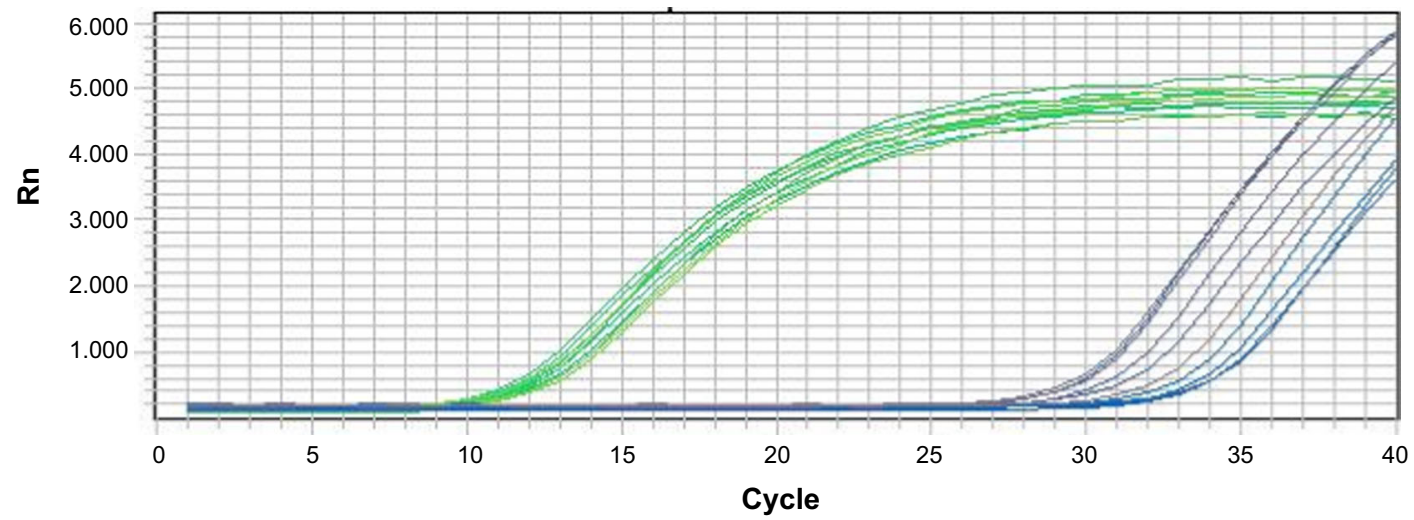

\begin{tabular}{c|c|c} 
& h18S mRNA & h $\beta 3$ AR mRNA \\
\hline Median Ct [IQR] & $8.66[0.90]$ & 31.55 [3.28]
\end{tabular}

Fig. 3 Ex vivo experiments in human pulmonary artery smooth muscle cells and pulmonary arteries. a Effect of BRL37344 on hypoxia-induced proliferation of human pulmonary artery smooth muscle cell proliferation. Cell proliferation was measured by cytometry after $72 \mathrm{~h}$ of hypoxia exposure. Data represent mean value and $\mathrm{SD}$ of three independent experiments. ${ }^{*} p<0.05 ; N S$ non significant. b Human b3AR mRNA expression in human pulmonary

peaked at 3-5 h and achieved steady-state within 7 days of once daily administration, similar as found in our experimental model.

All hemodynamic effects were similar for the two different selective $\beta 3 \mathrm{AR}$ agonists tested, which reinforces the results obtained and suggests that it is the target activation which is important and not the drug class per se. As expected, the effect of nebivolol was different because it possesses a $\beta 3 \mathrm{AR}$ agonist effect with a $\beta 1 \mathrm{AR}$ antagonist activity. Derived from its negative inotropic $\beta 1$ AR blocking effect, a neutral effect on cardiac index was observed, while a significant reduction of PVR was maintained. This result is consistent with recent data pointing to nebivolol as arteries $(N=10)$. Amplification curves for hb3AR (blue) and $18 \mathrm{~S}$ (green) mRNA expression. The values of the median $\mathrm{Ct}$ (IQR) are shown in the table. c Vasodilator effect of BRL37344 on human pulmonary arteries $(N=10)$. Relaxation of small pulmonary arteries to cumulative concentrations of BRL37344, expressed as \% of contraction to norepinephrine (NE). Maximal NE response was 18,495 (3420) $\mathrm{mN}$. Values are mean $\pm \mathrm{SD}$

a potential beneficial therapy for $\mathrm{PH}[29,31]$. Additionally, this third arm helped us exclude that the effect over PVR was derived from non-selective $\beta 1 \mathrm{AR}$ stimulation. However, although several studies have shown that nebivolol vasodilates in vitro [9] and in vivo [2] through an agonist effect on endothelial $\beta 3 \mathrm{ARs}$, other studies have failed to demonstrate binding to $\beta 3 \mathrm{AR}$ [12], so results obtained with nebivolol should be considered with caution since the degree they are produced by $\beta 3 \mathrm{AR}$ stimulation is uncertain.

The concentration of BRL37344 in plasma was around $3 \mathrm{ng} / \mathrm{mL}$ during first hours, reaching a steady-state concentration around $1 \mathrm{ng} / \mathrm{mL}$. Considering that the molecular weight of BRL37344 is $385.8 \mathrm{~g} / \mathrm{mol}$, the concentration 
achieved in our animals fell inside the concentration range that showed affectivity in vitro in human arteries $\left(10^{-6} \mathrm{M}\right.$ equals $0.38 \mathrm{ppb}$ and $10^{-5} \mathrm{M}$ equals $3.856 \mathrm{ppb}$ ). Based on studies evaluating selective signal transduction in the $\beta 3 \mathrm{AR}$ [3], we consider that these drug levels mainly acted through $\beta 3 \mathrm{AR}$ activation, as BRL37344 Ki values are 287 and $1750 \mathrm{nM}$ for $\beta 3$ and $\beta 1$ receptors, respectively. Similarly occured with mirabegron (EC50 of 22.4 (12.6-36.3) for $\beta 3$ vs. $>10,000$ for $\beta 1$ [34].

Hemodynamic changes with long-term $\beta 3 \mathrm{AR}$ agonist therapy were associated with an improvement in RV performance assessed by CMR, the gold-standard imaging technique, as evidenced by a decrease in RV end-systolic volume and an improvement in RV ejection fraction. This is relevant due to the prognostic importance of RV performance in chronic $\mathrm{PH}$.

The downstream pathway activated by $\beta 3 \mathrm{AR}$ agonists is known to include nitric oxide synthase, nitric oxide-activated guanylate cyclase and guanylate cyclase-cyclic guanylate monophosphate synthesis, and increased cyclic adenosine monophosphate synthesis [30]. Within the pulmonary circulation, cyclic nucleotides are responsible for mediating endothelium-dependent dilation but they also have beneficial effects on pulmonary vascular remodeling and RV function. In fact, in our study, long-term treatment with $\beta 3 \mathrm{AR}$ agonists in pigs with chronic $\mathrm{PH}$ was associated with changes in protein expression associated with a reduced vascular proliferation within the lung parenchyma, suggesting a beneficial protective effect against vascular remodeling. P27 is a key cyclin-dependent kinase inhibitor that blocks the G1 to S-phase transition in cell cycle progression and its role in pulmonary artery smooth muscle cell proliferation in $\mathrm{PH}$ has been repeatedly demonstrated $[20,39]$. In our study, a decrease in the expression of the cellular proliferation marker Ki67 was correlated with an increase in p27 expression in the lung parenchyma of pigs treated with mirabegron, in agreement with previous $\mathrm{PH}$ studies using different therapies [40]. Inhibition of hypoxia-induced proliferation was confirmed in human pulmonary artery smooth muscle cell cultures in vitro. The experiment performed suggested that this inhibitory effect was mediated by nitric oxide.

To the best of our knowledge, our study is the first to report the expression of $\beta 3 \mathrm{AR}$ mRNA and to evaluate the vasodilator effect of $\beta 3 \mathrm{AR}$ agonists in human pulmonary arteries. The magnitude of vasodilation observed was consistent with that found in vitro using BRL37344 in human internal mammary arteries [31] or pulmonary arteries from dogs [33].

Most experiments were performed in a translational large-animal model of chronic $\mathrm{PH}$. This model reproduces chronic $\mathrm{PH}$ changes in hemodynamics, $\mathrm{RV}$ remodeling and pathology [13, 28]. Several novel therapies have demonstrated beneficial effects in pre-clinical studies but have subsequently failed in the clinical arena. This poor translation is in part due to the absence of randomized studies in pre-clinical large-animal models. We have developed our pig model because of its anatomical and physiological similarities to humans. To facilitate the inference of our results to patients, all results were assessed using the same gold-standard methodologies used in clinical practice (right heart catheterization and CMR).

Some limitations should be acknowledged. Our pig model of post-capillary $\mathrm{PH}$ may not represent the entire spectrum of patients with $\mathrm{PH}$ due to left heart disease, especially because left ventricular function is preserved. However, our study aimed to evaluate the specific effect of $\beta 3 \mathrm{AR}$ agonists on the pulmonary circulation and the RV since the beneficial effect of $\beta 3 \mathrm{AR}$ agonists on left ventricular dysfunction has been previously studied. Overt RV dysfunction using this model was observed in few cases (only two animals with baseline RVEF $<50 \%$ ), thus precluding us to evaluate the effect of the new therapy in the setting of advanced RV dysfunction. Sample sizes were small and therefore, the study might have been underpowered to assess differences in some parameters like BP or HR. The current study focused on the evaluation of the effect of $\beta 3 \mathrm{AR}$ agonists in a translational animal model of chronic $\mathrm{PH}$. No $\beta 3 \mathrm{AR}$ antagonist or $\beta 2 \mathrm{AR}$ antagonist drugs were used, and therefore, we cannot exclude that part of the observed effects using BRL37344 and mirabegron were caused by $\beta 2 \mathrm{AR}$ stimulation. Further research, on the functional activity of $\beta 3 \mathrm{ARs}$ in human pulmonary arteries, and the effect of $\beta 3 \mathrm{AR}$ agonists on them is necessary, including mechanistic studies on the pathways involved. The LC-MS/MS method measured plasma levels of BRL37344 and mirabegron are not bound to plasma proteins. Differences in receptor activation and in protein binding may exist among species. Therefore and specifically, further studies aiming to evaluate the pharmacokinetic profile of the $\beta 3 \mathrm{AR}$ agonist treatments used in relation with the resultant activation on the target receptor in the pig and human are necessary.

In conclusion, $\beta 3 \mathrm{AR}$ agonists produced a significant reduction in PVRI and improved RV performance in a translational experimental large-animal model of $\mathrm{PH}$. $\beta 3 \mathrm{AR}$ agonists emerges as a potential novel approach for treating patients with $\mathrm{PH}$.

Acknowledgments Gonzalo J. López was responsible for the highquality CMR examinations. Tamara Córdoba, Oscar Sanz, Eugenio Fernández and the rest of the staff working in the animal facilities and CNIĆs farm were outstanding in animal care and unconditional support. We want to thank Pedro Molina for giving us the P27 antibody. 


\section{Compliance with ethical standards}

Conflict of interest Dr. Ibañez, Dr. García-Álvarez and Dr. Fuster have submitted the patent entitled "Use of selective beta-3 adrenergic agonists for the treatment of pulmonary hypertension" (PCT/ES2013/ 070611).

Sources of funding This work was supported by Fonde Europeo de Desarrollo Regional (FEDER) Instituto de Salud Carlos III-Fondo de Investigación Sanitaria PI13/02339 (to A. G-A), and the competitive grant "CNIC-Translational 01-2009"' (to BI). R F-J is recipient of a "Rio Hortega" fellowship granted by the ISCIII. R F-J is recipient of the "FICNIC" fellowship granted by the "Fundació Jesús Serra", "Fundación Interhospitalaria de Investigación Cardiovascular (FIC)" and CNIC. A. G-A, B. I, L. F-F, R. F-J, M. S and JM. G-R are members of "Red de Investigación Cardiovascular" (RIC RD12/ 0042/0006 and RD12/0042/0054) from the Ministerio de Economia y Competitividad, ISCIII". The CNIC is supported by the Spanish Ministry of Economy and Competitiveness (MINECO) and the ProCNIC Foundation, and is a Severo Ochoa Center of Excellence (MINECO award SEV-2015-0505).

Open Access This article is distributed under the terms of the Creative Commons Attribution 4.0 International License (http://crea tivecommons.org/licenses/by/4.0/), which permits unrestricted use, distribution, and reproduction in any medium, provided you give appropriate credit to the original author(s) and the source, provide a link to the Creative Commons license, and indicate if changes were made.

\section{References}

1. Andersen $\mathrm{KH}$, Iversen $\mathrm{M}$, Kjaergaard J, Mortensen J, NielsenKudsk JE, Bendstrup E, Videbaek R, Carlsen J (2012) Prevalence, predictors, and survival in pulmonary hypertension related to end-stage chronic obstructive pulmonary disease. J Heart Lung Transpl 31:373-380. doi:10.1016/j.healun.2011.11.020

2. Aragon JP, Condit ME, Bhushan S, Predmore BL, Patel SS, Grinsfelder DB, Gundewar S, Jha S, Calvert JW, Barouch LA, Lavu M, Wright HM, Lefer DJ (2011) Beta3-adrenoreceptor stimulation ameliorates myocardial ischemia-reperfusion injury via endothelial nitric oxide synthase and neuronal nitric oxide synthase activation. J Am Coll Cardiol 58:2683-2691. doi:10. 1016/j.jacc.2011.09.033

3. Blin N, Camoin L, Maigret B, Strosberg AD (1993) Structural and conformational features determining selective signal transduction in the beta 3-adrenergic receptor. Mol Pharmacol 44:1094-1104

4. Brody S (1928) A comparison of growth curves of man and other animals. Science 67:43-46. doi:10.1126/science.67.1724.43

5. Bundgaard H, Liu CC, Garcia A, Hamilton EJ, Huang Y, Chia KK, Hunyor SN, Figtree GA, Rasmussen HH (2010) Beta(3) adrenergic stimulation of the cardiac $\mathrm{Na}+-\mathrm{K}+$ pump by reversal of an inhibitory oxidative modification. Circulation 122:2699-2708. doi:10.1161/CIRCULATIONAHA.110.964619

6. Chang PP, Longenecker JC, Wang NY, Baughman KL, Conte JV, Hare JM, Kasper EK (2005) Mild vs. severe pulmonary hypertension before heart transplantation: different effects on posttransplantation pulmonary hypertension and mortality. J Heart Lung Transpl 24:998-1007. doi:10.1016/j.healun.2004.07.013

7. Chapple CR, Cardozo L, Nitti VW, Siddiqui E, Michel MC (2014) Mirabegron in overactive bladder: a review of efficacy, safety, and tolerability. Neurourol Urodyn 33:17-30. doi:10. 1002/nau.22505
8. Dessy C, Moniotte S, Ghisdal P, Havaux X, Noirhomme P, Balligand JL (2004) Endothelial beta3-adrenoceptors mediate vasorelaxation of human coronary microarteries through nitric oxide and endothelium-dependent hyperpolarization. Circulation 110:948-954. doi:10.1161/01.CIR.0000139331.85766.AF

9. Dessy C, Saliez J, Ghisdal P, Daneau G, Lobysheva II, Frerart F, Belge C, Jnaoui K, Noirhomme P, Feron O, Balligand JL (2005) Endothelial beta3-adrenoreceptors mediate nitric oxide-dependent vasorelaxation of coronary microvessels in response to the third-generation beta-blocker nebivolol. Circulation 112:1198-1205. doi:10.1161/CIRCULATIONAHA.104.532960

10. Dumas M, Dumas JP, Bardou M, Rochette L, Advenier C, Giudicelli JF (1998) Influence of beta-adrenoceptor agonists on the pulmonary circulation. Effects of a beta3-adrenoceptor antagonist, SR 59230A. Eur J Pharmacol 348:223-228. doi:10.1016/ S0014-2999(98)00146-0

11. Eltink C, Lee J, Schaddelee M, Zhang W, Kerbusch V, Meijer J, van Marle S, Grunenberg N, Kowalski D, Drogendijk T, Moy S, Iitsuka H, van Gelderen M, Matsushima H, Sawamoto T (2012) Single dose pharmacokinetics and absolute bioavailability of mirabegron, a beta(3)-adrenoceptor agonist for treatment of overactive bladder. Int $\mathrm{J}$ Clin Pharmacol Ther 50:838-850. doi: 10.5414/CP201782

12. Frazier EP, Michel-Reher MB, van Loenen P, Sand C, Schneider T, Peters SL, Michel MC (2011) Lack of evidence that nebivolol is a beta(3)-adrenoceptor agonist. Eur J Pharmacol 654:86-91. doi:10.1016/j.ejphar.2010.11.036

13. Garcia-Alvarez A, Fernandez-Friera L, Garcia-Ruiz JM, NunoAyala M, Pereda D, Fernandez-Jimenez R, Guzman G, SanchezQuintana D, Alberich-Bayarri A, Pastor-Escuredo D, Sanz-Rosa D, Garcia-Prieto J, Mirelis JG, Pizarro G, Jimenez-Borreguero LJ, Fuster V, Sanz J, Ibanez B (2013) Noninvasive monitoring of serial changes in pulmonary vascular resistance and acute vasodilator testing using cardiac magnetic resonance. J Am Coll Cardiol. doi:10.1016/j.jacc.2013.07.037

14. Garcia-Prieto J, Garcia-Ruiz JM, Sanz-Rosa D, Pun A, GarciaAlvarez A, Davidson SM, Fernandez-Friera L, Nuno-Ayala M, Fernandez-Jimenez R, Bernal JA, Izquierdo-Garcia JL, JimenezBorreguero J, Pizarro G, Ruiz-Cabello J, Macaya C, Fuster V, Yellon DM, Ibanez B (2014) beta3 adrenergic receptor selective stimulation during ischemia/reperfusion improves cardiac function in translational models through inhibition of mPTP opening in cardiomyocytes. Basic Res Cardiol 109:422. doi:10.1007/ s00395-014-0422-0

15. Guazzi M, Borlaug BA (2012) Pulmonary hypertension due to left heart disease. Circulation 126:975-990. doi:10.1161/CIRCU LATIONAHA.111.085761

16. Hoeper MM, Bogaard HJ, Condliffe R, Frantz R, Khanna D, Kurzyna M, Langleben D, Manes A, Satoh T, Torres F, Wilkins MR, Badesch DB (2013) Definitions and diagnosis of pulmonary hypertension. J Am Coll Cardiol 62:D42-D50. doi:10.1016/j. jacc.2013.10.032

17. Humbert M, Morrell NW, Archer SL, Stenmark KR, MacLean MR, Lang IM, Christman BW, Weir EK, Eickelberg O, Voelkel NF, Rabinovitch M (2004) Cellular and molecular pathobiology of pulmonary arterial hypertension. J Am Coll Cardiol 43:13S24S. doi:10.1016/j.jacc.2004.02.029

18. Iitsuka H, Tokuno T, Amada Y, Matsushima H, Katashima M, Sawamoto $\mathrm{T}$, Takusagawa $\mathrm{S}$, van Gelderen $\mathrm{M}$, Tanaka $\mathrm{T}$, Miyahara H (2014) Pharmacokinetics of mirabegron, a beta3adrenoceptor agonist for treatment of overactive bladder, in healthy Japanese male subjects: results from single- and multipledose studies. Clin Drug Investig 34:27-35. doi:10.1007/s40261013-0146-1

19. Krauwinkel W, van Dijk J, Schaddelee M, Eltink C, Meijer J, Strabach G, van Marle S, Kerbusch V, van Gelderen M (2012) 
Pharmacokinetic properties of mirabegron, a beta3-adrenoceptor agonist: results from two phase I, randomized, multiple-dose studies in healthy young and elderly men and women. Clin Ther 34:2144-2160. doi:10.1016/j.clinthera.2012.09.010

20. Luo Y, Zhang B, Dong HY, Liu Y, Li ZC, Dong MQ, Gao YQ (2014) Prevention of hypoxic pulmonary hypertension by hypoxia-inducible expression of p27 in pulmonary artery smooth muscle cells. Gene Ther 21:751-758. doi:10.1038/gt.2014.49

21. McLaughlin VV, Archer SL, Badesch DB, Barst RJ, Farber HW, Lindner JR, Mathier MA, McGoon MD, Park MH, Rosenson RS, Rubin LJ, Tapson VF, Varga J, Harrington RA, Anderson JL, Bates ER, Bridges CR, Eisenberg MJ, Ferrari VA, Grines CL, Hlatky MA, Jacobs AK, Kaul S, Lichtenberg RC, Moliterno DJ, Mukherjee D, Pohost GM, Schofield RS, Shubrooks SJ, Stein JH, Tracy CM, Weitz HH, Wesley DJ (2009) ACCF/AHA 2009 expert consensus document on pulmonary hypertension: a report of the American College of Cardiology Foundation Task Force on Expert Consensus Documents and the American Heart Association: developed in collaboration with the American College of Chest Physicians, American Thoracic Society, Inc., and the Pulmonary Hypertension Association. Circulation 119:2250-2294. doi:10.1161/CIRCULATIONAHA.109.192230

22. Mehra MR, Kobashigawa J, Starling R, Russell S, Uber PA, Parameshwar J, Mohacsi P, Augustine S, Aaronson K, Barr M (2006) Listing criteria for heart transplantation: international society for heart and lung transplantation guidelines for the care of cardiac transplant candidates-2006. J Heart Lung Transpl 25:1024-1042. doi:10.1016/j.healun.2006.06.008

23. Moniotte S, Kobzik L, Feron O, Trochu JN, Gauthier C, Balligand JL (2001) Upregulation of beta(3)-adrenoceptors and altered contractile response to inotropic amines in human failing myocardium. Circulation 103:1649-1655. doi:10.1161/01.CIR.103. 12.1649

24. Moraes DL, Colucci WS, Givertz MM (2000) Secondary pulmonary hypertension in chronic heart failure: the role of the endothelium in pathophysiology and management. Circulation 102:1718-1723. doi:10.1161/01.CIR.102.14.1718

25. Niu X, Watts VL, Cingolani OH, Sivakumaran V, Leyton-Mange JS, Ellis CL, Miller KL, Vandegaer K, Bedja D, Gabrielson KL, Paolocci N, Kass DA, Barouch LA (2012) Cardioprotective effect of beta-3 adrenergic receptor agonism: role of neuronal nitric oxide synthase. J Am Coll Cardiol 59:1979-1987. doi:10.1016/j. jacc.2011.12.046

26. Niu X, Zhao L, Li X, Xue Y, Wang B, Lv Z, Chen J, Sun D, Zheng Q (2014) Beta3-adrenoreceptor stimulation protects against myocardial infarction Injury via eNOS and nNOS activation. PLoS One 9:e98713. doi:10.1371/journal.pone.0098713

27. Peinado VI, Barbera JA, Ramirez J, Gomez FP, Roca J, Jover L, Gimferrer JM, Rodriguez-Roisin R (1998) Endothelial dysfunction in pulmonary arteries of patients with mild COPD. Am J Physiol 274:L908-L913

28. Pereda D, Garcia-Alvarez A, Sanchez-Quintana D, Nuno M, Fernandez-Friera L, Fernandez-Jimenez R, Garcia-Ruiz JM, Sandoval E, Aguero J, Castella M, Hajjar RJ, Fuster V, Ibanez B (2014) Swine model of chronic postcapillary pulmonary hypertension with right ventricular remodeling: long-term characterization by cardiac catheterization, magnetic resonance, and pathology. J Cardiovasc Transl Res 7:494-506. doi:10.1007/ s12265-014-9564-6

29. Perros F, Ranchoux B, Izikki M, Bentebbal S, Happe C, Antigny F, Jourdon P, Dorfmuller P, Lecerf F, Fadel E, Simonneau G,
Humbert M, Bogaard HJ, Eddahibi S (2015) Nebivolol for improving endothelial dysfunction, pulmonary vascular remodeling, and right heart function in pulmonary hypertension. J Am Coll Cardiol 65:668-680. doi:10.1016/j.jacc.2014.11.050

30. Rozec B, Gauthier C (2006) Beta3-adrenoceptors in the cardiovascular system: putative roles in human pathologies. Pharmacol Ther 111:652-673. doi:10.1016/j.pharmthera.2005.12.002

31. Rozec B, Serpillon S, Toumaniantz G, Seze C, Rautureau Y, Baron O, Noireaud J, Gauthier C (2005) Characterization of beta3-adrenoceptors in human internal mammary artery and putative involvement in coronary artery bypass management. J Am Coll Cardiol 46:351-359. doi:10.1016/j.jacc.2005.03.061

32. Swiston JR, Johnson SR, Granton JT (2010) Factors that prognosticate mortality in idiopathic pulmonary arterial hypertension: a systematic review of the literature. Respir Med 104:1588-1607. doi:10.1016/j.rmed.2010.08.003

33. Tagaya E, Tamaoki J, Takemura H, Isono K, Nagai A (1999) Atypical adrenoceptor-mediated relaxation of canine pulmonary artery through a cyclic adenosine monophosphate-dependent pathway. Lung 177:321-332

34. Takasu T, Ukai M, Sato S, Matsui T, Nagase I, Maruyama T, Sasamata M, Miyata K, Uchida H, Yamaguchi O (2007) Effect of (R)-2-(2-aminothiazol-4-yl)-4'-\{2-[(2-hydroxy-2-phenylethyl)amino]ethyl $\}$ acetanilide (YM178), a novel selective beta3adrenoceptor agonist, on bladder function. J Pharmacol Exp Ther 321:642-647. doi:10.1124/jpet.106.115840

35. Tantini B, Manes A, Fiumana E, Pignatti C, Guarnieri C, Zannoli R, Branzi A, Galie N (2005) Antiproliferative effect of sildenafil on human pulmonary artery smooth muscle cells. Basic Res Cardiol 100:131-138. doi:10.1007/s00395-004-0504-5

36. Uhlen M, Fagerberg L, Hallstrom BM, Lindskog C, Oksvold P, Mardinoglu A, Sivertsson A, Kampf C, Sjostedt E, Asplund A, Olsson I, Edlund K, Lundberg E, Navani S, Szigyarto CA, Odeberg J, Djureinovic D, Takanen JO, Hober S, Alm T, Edqvist PH, Berling H, Tegel H, Mulder J, Rockberg J, Nilsson P, Schwenk JM, Hamsten M, von Feilitzen K, Forsberg M, Persson L, Johansson F, Zwahlen M, von Heijne G, Nielsen J, Ponten F (2015) Proteomics. Tissue-based map of the human proteome. Science 347:1260419. doi:10.1126/science.1260419

37. Vachiery JL, Adir Y, Barbera JA, Champion H, Coghlan JG, Cottin V, De Marco T, Galie N, Ghio S, Gibbs JS, Martinez F, Semigran M, Simonneau G, Wells A, Seeger W (2013) Pulmonary hypertension due to left heart diseases. J Am Coll Cardiol 62:D100-D108. doi:10.1016/j.jacc.2013.10.033

38. Wharton J, Strange JW, Moller GM, Growcott EJ, Ren X, Franklyn AP, Phillips SC, Wilkins MR (2005) Antiproliferative effects of phosphodiesterase type 5 inhibition in human pulmonary artery cells. Am J Respir Crit Care Med 172:105-113. doi:10.1164/rccm.200411-1587OC

39. Xu DQ, Luo Y, Liu Y, Wang J, Zhang B, Xu M, Wang YX, Dong HY, Dong MQ, Zhao PT, Niu W, Liu ML, Gao YQ, Li ZC (2010) Beta-estradiol attenuates hypoxic pulmonary hypertension by stabilizing the expression of p27kip1 in rats. Respir Res 11:182. doi:10.1186/1465-9921-11-182

40. Yu L, Quinn DA, Garg HG, Hales CA (2005) Cyclin-dependent kinase inhibitor $\mathrm{p} 27 \mathrm{Kip} 1$, but not $\mathrm{p} 21 \mathrm{WAF} 1 / \mathrm{Cip} 1$, is required for inhibition of hypoxia-induced pulmonary hypertension and remodeling by heparin in mice. Circ Res 97:937-945. doi:10. 1161/01.RES.0000188211.83193.1a 